doi:10.18575/msrs.sm.e.16.26

UDK 616.718.5-001.5-089.881 COBISS.RS-ID 6165784

\title{
Tibial Intercondylar Eminence Fracture
}

\begin{abstract}
Introduction: Tibial intercondylar eminence fractures are uncommon injuries, occurring mainly in adolescents and young adults. When necessary, regardless of patient age, anatomic reduction and stable internal fixation are mandatory for fracture healing and accurate restoration of normal knee biomechanics. There are various arthroscopically assisted fixation methods (sutures, anchors, wires, or screws). We present a case, in which we reduced the fracture using fiber wire suture, fixing it with EndoButton $®$ on the medial tibial tuberosity, with a clinical and radiological follow-up of three months.
\end{abstract}

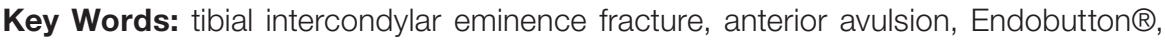
knee arthroscopy.

\section{Michele Bisaccia, ${ }^{1}$ Giovanni Colleluori, ${ }^{1}$ Luigi Meccariello, ${ }^{2}$ Gabriele Falzarano, ${ }^{3}$ Antonio Medici, ${ }^{3}$ Luigi Piscitelli, ${ }^{1}$ Cristina Ibáñez Vicente, ${ }^{1}$ Auro Caraffa ${ }^{1}$}

\author{
1. Division of Orthopedics and \\ Trauma Surgery, University of \\ Perugia, S. Maria della Misericordia \\ Hospital. \\ 2. Department of Medical and \\ Surgical Sciences and \\ Neuroscience, Section of Orthopedics \\ and Traumatology, University of \\ Siena, University Hospital "Santa \\ Maria alle Scotte", Siena, Italy \\ 3. U.O.C. Orthopedics and \\ Traumatology, Azienda Ospedaliera \\ "Gaetano Rummo", Benevento, Italy
}

\section{Contact address:}

Luigi Meccariello, $M D$

Department of Medical and Surgical Science and Neuroscience, Section of Orthopedics and Traumatology, University of Siena, University Hospital

"Santa Maria alle Scotte",

Viale Bracci 1, 53100 Siena, Italy E-mail:

drlordmec@gmail.com

Telephone: +393299419574.

Submitted: May 27 ${ }^{\text {th }}, 2016$ Accepted: June 26 ${ }^{\text {th }}, 2016$

\section{Introduction}

Tibial intercondylar eminence fractures, characterized by fractures at the insertion site of the anterior cruciate ligament (ACL) on the tibia, lead to joint dysfunction. These injuries are rare, affecting only three in every 100,000.

These injuries are commonly seen in children age between 8-13 years and are usually sport related injury, occurring especially during skiing or cycling. These injuries are correlated to high energy trauma, such as road traffic accidence. The anterior tibial spine is injured ten times more frequently than the posterior tibial insertion. ${ }^{3}$ In 1959 , Meyers and McKeever ${ }^{4}$ proposed a classification system for these fractures as follows: type I fractures are not displaced; type II, angular elevation of the anterior portion with full posterior hinging, resembling a "bird- beak"; and type III fractures are completely displaced. Later, Zaricznyj ${ }^{5}$ added type IV - complete multifragmental fracture. Fractures of the intercondylar eminence are more thoroughly described in the paediatric orthopaedic literature and occur at lower frequency in adults. Optimal treatment methods remain controversial and are varied by classification type, surgeon preference, and patient age. Furthermore, the evolution of arthroscopic techniques and the possibility of extension loss after conservative treatment of type II fractures have increased the tendency toward operative treatment of these fractures. Unfortunately, the bibliography on this subject is quite limited. 


\section{Case report}

We described a 28-year-old woman who fell in a hole with direct trauma to her right knee. She was initially admitted to the emergency service, where the initial radiographs were obtained (Fig.1a-b). They showed a tibial avulsion fracture of the anterior and cruciate ligament.

Figure 1. Tibial intercondylar eminence fracture(a) with LCA dysfunction(b)

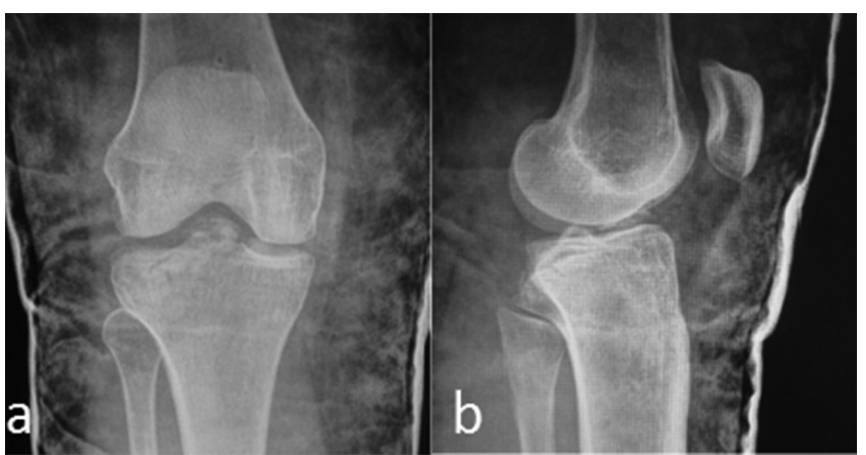

Upon the admission, clinical examination showed the Tegner-Lysholm skore of 35 points. The knee was painful, effusion $++/ 4$, Lachmann ++ , anterior drawer + and posterior drawer ++ , and was negative for varus and valgus stress. Computed tomography (Fig.2a-b) was requested. The diagnosis was confirmed and the avulsion was classified as Meyers and McKeever type III.

Figure 2. Computed tomography confirmed the tibial intercondylar eminence fracture
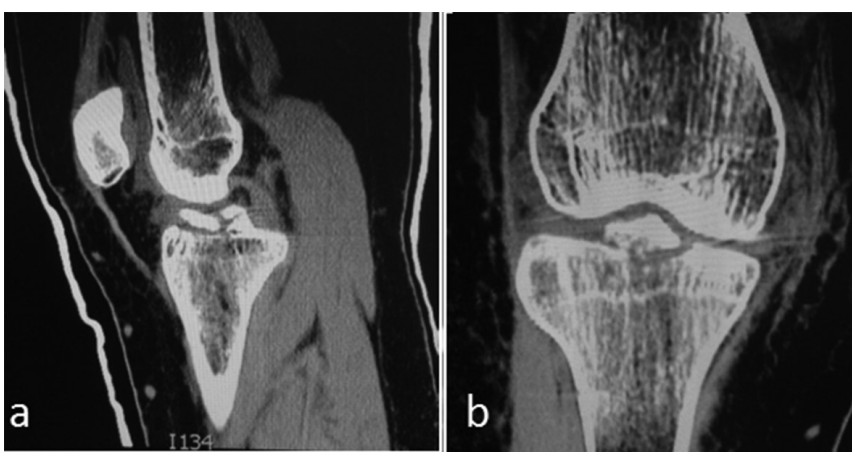

Afterwards, the decision was made to conduct a surgery treatment.

The patient was positioned supine with a thigh tourniquet. Using a 30,4.0- mm arthoscope, three arthroscopic portals were used: a standard lateral portal, an anteromedial portal medial to the patellar tendon and a far medial portal. A diagnostic arthroscopy was performed, hemartrosis was evacuated from the joint and the fracture was visualized. The underlying tibial cancellous bone was cleaned with a shaver and slightly deepened, allowing for a slight over reduction of the fracture. Fracture was reduced using fiber wire suture, fixing it with EndoButton $\AA$ on the medial tibial tuberosity. The patient was discharged from hospital two days after the surgery, with an immobilizer, prophylactic antibiotics (amoxicillin 1 gr a day for 7 days) and prophylaxis for deep vein thrombosis (enoxaparin sodium, 4000 U.I., $1 \mathrm{fl} /$ die per 15 days), and was instructed not to put her body weight on the operated limb. Ten days after the operation, physiotherapy programme, consisting of isotonic and isometric exercises and flexion-extension, started. On the 3oth day after the operation, the patient attained range of motion of $0-90^{\circ}$. On the 6oth day of follow-up, the patient presented range of motion of $0-100^{\circ}$, with radiographs that showed consolidation of the fractures and absolutely anatomical reduction of the spine (Fig.3).

Fifure 3. Three months after the treatment, consolidation of fracture

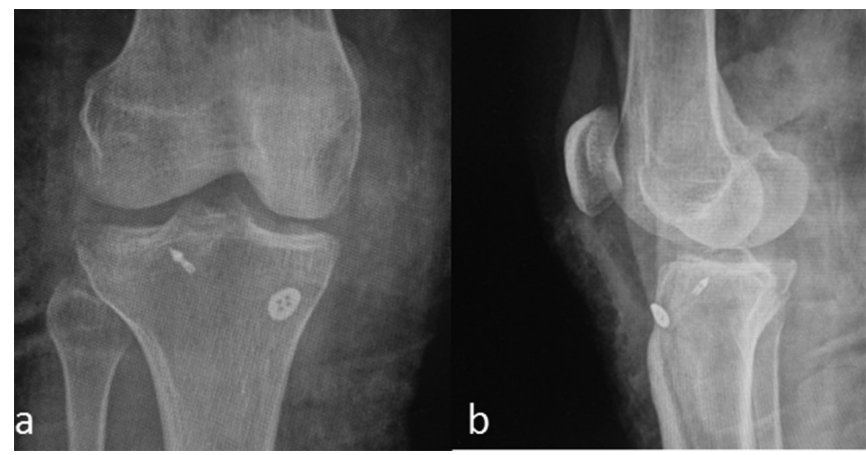

The patient was then advised to partially bear weight on the limb, with crutches. After 10 weeks of follow-up, she was suggested full weight-bearing, while continuing with the rehabilitation protocol. From then on, the patient was controlled every month. Three months after the treatment, radiography showed that the patient was free from symptoms. She had already returned to her habitual working activities. The Tegner-Lysholm knee evaluation score was 94 (good result); her range of motion was $0-115^{\circ}$; she was negative for Lachmann tests, negative for anterior and posterior drawers, negative for pivot shift and negative for varus and valgus stress.

\section{Discussion}

Tibial intercondylar eminence fractures are not common. They occur mainly in adolescents or young adults during sporting activities or even bicycle or car accidents. When not fixed, these fractures cause knee disability and reduce working ability. Their management has evolved from traditional conservative treatment to surgical treatment using different techniques. Several surgical treatments have been proposed for these injuries, going from the conventional open procedure to inclusion of arthroscopic methods, which were first described by McLennan ${ }^{6}$ in 1982 with a number of fixation methods: Kirschner 
wires, cannulated screws, sutures with steel or polyester wires, anchors and EndoButton $\AA$. While the results from primary fixation in skeletally immature patients are good, the treatments in adults present variable results and some authors have reported high rates of incidence of postoperative complications. ${ }^{7}$ According to classification of Meyers and McKeever ${ }^{8}$ proposed in 1970, and subsequently modified by Zarincznyj, ${ }^{5}$ we can predict the best treatment in relation to each type of fracture. It is recommended that fractures without displacement (Type I) should be treated conservatively; moderately displaced fractures (Type II) can be managed conservatively or surgically; and displaced fractures (Type III) and comminuted fractures (Type IV) have surgical indications. The type of surgical treatment depends on the position and size of the avulsed fracture.

In 2011, Shelbourne et al. ${ }^{9}$ reported that the most common forms of treatment for this type of injury might equally be open or arthroscopic reduction, although controversy remained regarding which treatment method was best. In 2012, Hapa et al. ${ }^{10}$ conducted a biomechanical study on sheep and affirmed that fixation using EndoButton for fractures of the tibial eminence produced initial fixation strength that was greater than with fixation using anchors or other types of suture. For functional evaluation, Lysholm and Gillquist developed a scale of knee symptoms. The Lysholm scale includes basic aspects of the Larson scale, but introduces the criteria of instability and correlates it with activity. This scale was modified by Tegner and Lysholm. These authors recognized the difficulty in having a score for ligament injuries and decided at that juncture to investigate clinical findings and evaluate symptoms and functions. This scale or questionnaire by Lysholm is composed on eight questions, with options for closed responses, in which the final result is expressed in nominal and ordinal form, such that "excellent" is $95^{-100}$ points, "good" is $84-94$ points, "fair" is $65-83$ points and "poor" is less than or equal to 64 points.

\section{Conclusion}

To conclude, we can say that the treatment of the avulsion fractures of the ACL is one of the most complex procedures in orthopaedic surgery. Unfortunately, both conservative and surgical treatments have no guarantees of complete success. The choice of the type of treatment has to be evaluated considering the age, the anatomical congruence and the functional request of the patient.

\section{Reference}

1. Baums H.-M. Klinger T. Härer. Treatment of malunited fractures of the anterior tibial spine. Knee Surg Sports Traumatol Arthrosc 2004; 12 :159-161 http://dx.doi.org/10.1007/s00167-003-0387-2 PMid:12879226
2. Iborra JP, Mazeau P, Louahem D, Diméglio A. Fractures of the intercondylar eminence of the tibia in children. Apropos of 25 cases with a 1-20 year follow up. Rev Chir Orthop Reparatrice Appar Mot 1999 ;85(6):563-73.

3. Estes AR, Oladeji LO Arthroscopic treatment of tibial spine malunion with resorbable screws. Am J Orthop 2015;44(5):E160-4. PMid:25950547

4. Lukás L, Koudela K. Fractures of the intercondylar eminence of the tibia. Acta Chir Orthop Traumatol Cech. 2004;71(3):171-5. PMid:15307303

5. Zaricznyj B Avulsion fracture of the tibial eminence: treatment by open reduction and pinning. J Bone Joint Surg Am. 1977 Dec;59(8):1111-4.

PMid:591548

6. Ochiai S, Hagino T, Watanabe Y, Senga S, Haro H. One strategy for arthroscopic suture fixation of tibial intercondylar eminence fractures using the Meniscal Viper Repair System. Sports Med Arthrosc Rehabil Ther Technol2011;3:17. http://dx.doi.org/10.1186/1758-2555-3-17 PMid:21831294 PMCid:PMC3163208

7. Ahn JH, Yoo JC. Clinical outcome of arthroscopic reduction and suture for displaced acute and chronic tibial spine fractures. Knee Surg Sports Traumatol Arthrosc. 2005;13(2):116-21.

http://dx.doi.org/10.1007/s00167-004-0540-6 PMid:15756616

8. Kieser DC, Gwynne-Jones D, Dreyer S. Displaced tibial intercondylar eminence fractures. J Orthop Surg 2011;19(3):292-6. http://dx.doi.org/10.1177/230949901101900306

9. Shelbourne KD, Urch SE, Freeman H. Outcomes after arthroscopic excision of the bony prominence in the treatment of tibial spine avulsion fractures. Arthroscopy $2011 \mathrm{~J} ; 27(6): 784-91$.

10. Hapa O, Barber FA, Süner G, Özden R, Davul S, Bozdağ E, Sünbüloğlu E. Biomechanical comparison of tibial eminence fracture fixation with high-strength suture, EndoButton, and suture anchor. Arthroscopy 2012 May;28(5):681-7. http://dx.doi.org/10.1016/j.arthro.2011.10.026 PMid:22284410 


\section{Prelom interkondilarne eminencije tibije}

\section{SAŽETAK}

Uvod: Prelom tibijalne interkondilarne eminencije je rijetka povreda koja se javlja uglavnom kod mladih sportista u adolescentno doba,. Bez obzira na starosnu dob pacijenta, narušena je anatomska stabilnost koljena. Obaveza hirurškog liječenja preloma je anatomska repozicija i stabilna fiksacija preloma. Anatomskom repozicijom i stabilnom osteositezom se postiže fiziološka funkcionalnost i stabilnost koljena. Postoje različita sredstva (konac, žice, zavrtnji) kojima se stabilizuje interkondilarna eminencija. Prikazujemo slučaj gdje smo stabilizovali tibijalni prelom interkondilarne eminencije upotrebom EndoButton® uz kliničko i radiološko praćenje od tri mjeseca.

Ključne riječi: prelom tibijalne interkondilarne eminencije, EndoButton®, artroskopija 